\title{
Biomass Plug Development and Propagation in Porous Media
}

\author{
Terri L. Stewart, ${ }^{*}$ H. Scott Fogler \\ Department of Chemical Engineering, University of Michigan, $3168 \mathrm{H} . \mathrm{H}$. \\ Dow Building, Ann Arbor, Michigan 48109-2136; telephone: 313-763-1361; \\ fax: 313-763-0459; e-mail address: sfogler@engin.umich.edu
}

Received 20 April 2000; accepted 5 September 2000

\begin{abstract}
Exopolymer-producing bacteria can be used to modify soil profiles for enhanced oil recovery or bioremediation. Understanding the mechanisms associated with biomass plug development and propagation is needed for successful application of this technology. These mechanisms were determined from packed-bed and micromodel experiments that simulate plugging in porous media. Leuconostoc mesenteroides was used, because production of dextran, a water-insoluble exopolymer, can be controlled by using different carbon sources. As dextran was produced, the pressure drop across the porous media increased and began to oscillate. Three pressure phases were identified under exopolymer-producing conditions: the exopolymer-induction phase, the plugging phase, and the plug-propagation phase. The exopolymer-induction phase extended from the time that exopolymer-producing conditions were induced until there was a measurable increase in pressure drop across the porous media. The plugging phase extended from the first increase in pressure drop until a maximum pressure drop was reached. Changes in pressure drop in these two phases were directly related to biomass distribution. Specifically, flow channels within the porous media filled with biomass creating a plugged region where convective flow occurred only in water channels within the biofilm. These water channels were more restrictive to flow causing the pressure drop to increase. At a maximum pressure drop across the porous media, the biomass yielded much like a Bingham plastic, and a flow channel was formed. This behavior marked the onset of the plug-propagation phase which was characterized by sequential development and breakthrough of biomass plugs. This development and breakthrough propagated the biomass plug in the direction of nutrient flow. The dominant mechanism associated with all three phases of plugging in porous media was exopolymer production; yield stress is an additional mechanism in the plug-propagation phase. (C) 2001 John Wiley \& Sons, Inc. Biotechnol Bioeng 72: 353-363, 2001.
\end{abstract}

Keywords: Leuconostoc mesenteroides; biomass plugging; porous media; mechanisms; bacterial profile modification

\section{INTRODUCTION}

Bacteria that produce exopolymers have been considered for use in modifying the injection profile of a reservoir to

Correspondence to: H. Scott Fogler

* Present address: Pacific Northwest National Laboratory, P.O. Box 999, Richland, Washington 99352 enhance oil recovery; the approach is referred to as bacterial profile modification. The concept of controlled plugging of porous media with biomass (i.e., bacterial cells and exopolymers) can also be considered for use in bioremediation. In this application, an impermeable biobarrier can be formed with an exopolymer-producing bacteria to divert groundwater around a contaminated zone.

These concepts evolved from early studies of the impact of bacterial growth and exopolymer production in porous media. Researchers interested in understanding the cause of well-clogging found that bacteria, especially slimeproducing bacteria, were associated with permeability reduction (Kalish et al., 1964). It was found that rapid clogging of soils through which waste water or sewage percolated was related to the accumulation of bacterial polysaccharide in the soils (Mitchell and Nevo, 1964). Additionally, polysaccharide production from both aerobic and anaerobic bacteria was found to cause significant reduction in the permeability of sintered glass bead cores; aerobic bacteria caused plugging near the inlet surface and anaerobic bacteria caused plugging throughout the core (Shaw et al., 1985). It was subsequently confirmed that both growth and slime production contributed to biological plugging of an oil field core with the highest cell densities and slime concentration near the inlet (Geesey et al., 1987). Comparative studies of bacteria that formed capsules and those that produced slime were conducted (Vandevivere and Baveye, 1992). It was determined that all strains in these tests caused plugging when colonized in the inlet chamber of a sand column, but that only slime-producing bacteria caused a reduction in hydraulic conductivity when the sand column was inoculated downstream of the inlet chamber.

Bacteria and conditions that could be used for bacterial profile modification have been evaluated in recent years. Research to demonstrate that nutrients and bacteria could be transported through porous media and induce plugging was a precursor to determining the viability of bacterial profile modification (Jenneman et al., 1984; Parli et al., 1998; Raiders et al., 1985). The species, Leuconostoc mesenteroides (NRRL B523; ATCC 14935), was identified as a feasible candidate for use in bacterial profile modification, because its exopolymer production can be controlled by use of different carbon sources (Jack et al., 1983). When sucrose is 
provided as the carbon source, the cells grow and produce water-insoluble dextran, an exopolysaccharide comprised of repeating glucose units linked with 1-3 (24\%), 1-4 (10\%), and 1-6 (66\%) glucosidic bonds (Jeanes et al., 1954). However, when glucose and fructose are used as carbon sources, cell growth occurs without dextran production. This characteristic allows for the possibility of exopolymer-free cells to be injected and dispersed deeply into a formation before initiating production of dextran in situ, which causes the decrease in permeability (Jack and DiBlasio, 1985; Jack et al., 1983; Jack et al., 1989; Jack et al., 1991).

Lappan and Fogler (1992) used Leuconostoc mesenteroides as a model bacteria to better understand bacterial plugging of porous media due to the presence (or absence) of exopolymers. It was found that, in highly permeable ceramic cores, permeability reduction occurred when cells produced dextran, but there was no reduction in the permeability in the absence of this exopolymer (Lappan and Fogler, 1992). In parallel core-flood experiments, flow was diverted from highly permeable cores to less permeable cores when exopolymer-producing conditions were used (Lappan and Fogler, 1996). With continued nutrient injection, however, flow was diverted back to the highly permeable core, which is undesirable in bacterial profile modification applications. Hence, the kinetics for growth and exopolymer production were determined to gain insight into the feeding strategy that would lead to controlled permeability reduction (Lappan, 1994; Lappan and Fogler, 1994).

Flow and reaction experiments were also conducted by Lappan (1994) to evaluate the effects of nutrient concentration and flow rate on plugging of ceramic cores. The pressure drop across the core was recorded as a function of time. Pressure data were collected at more frequent intervals than in earlier-core flooding experiments, i.e., $15 \mathrm{~min}$ vs 1 to $5 \mathrm{~h}$. With more frequent data collection, large pressure oscilla- tions were measured as injection of nutrient continued (Lappan, 1994; Lappan and Fogler, 1996). Further investigation to determine the mechanism(s) for plug development and propagation is required to better understand the cause of these pressure oscillations and is the focus of the research presented in this article.

\section{MATERIALS AND METHODS}

\section{Bacteria}

The bacteria used in these experiments is Leuconostoc mesenteroides (NRRL B523; ATCC 14935). It is a facultative anaerobe that grows under mesophilic conditions. The cells are coccoidal having an average diameter of $1 \mu \mathrm{m}$ and occur as singlets, doublets, or short chains under the nutrient-rich conditions used in this research. The bacterial cells were prepared from a stock culture stored at $-40^{\circ} \mathrm{C}$. The inoculum was grown in a batch reactor with nutrient containing salts, trace minerals, $10 \mathrm{~g} / \mathrm{L}$ yeast extract, and $7.9 \mathrm{~g} / \mathrm{L}$ each of glucose and fructose as shown in Table I.

\section{Packed-Bed Equipment}

The packed bed used in this experiment consisted of glass beads with an average diameter of $300 \mu \mathrm{m}$. Dry beads were poured into a section of heat-shrink tubing that had been cut to the desired length. Stainless steel mesh and $0.635-\mathrm{cm}-$ thick stainless steel distributors were positioned on both ends to contain the beads without restricting fluid flow. A heat gun was used to uniformly shrink the tubing. The total length of the packed bed was $5.75 \mathrm{~cm}$ with a diameter of 2.5 $\mathrm{cm}$, nominally. Porosity was $38 \%$, pore volume was $8 \mathrm{~mL}$, and the permeability was 10 Darcies. The packed bed was saturated with deionized water and a tracer was injected to

Table I. Conditions for packed-bed and micromodel experiments.

\begin{tabular}{|c|c|c|}
\hline & Conditions for Packed Bed & Conditions for Micromodel \\
\hline Inoculum growth media & $\begin{array}{l}\text { 7.9 g/L each glucose and fructose with } 10 \mathrm{~g} / \mathrm{L} \text { yeast ex- } \\
\text { tract in mineral water }{ }^{\mathrm{a}}\end{array}$ & $\begin{array}{l}7.9 \mathrm{~g} / \mathrm{L} \text { each glucose and fructose with } 10 \mathrm{~g} / \mathrm{L} \text { yeast extract } \\
\text { in mineral water }\end{array}$ \\
\hline Saturation solution & $\begin{array}{l}7.9 \mathrm{~g} / \mathrm{L} \text { each glucose and fructose with } 10 \mathrm{~g} / \mathrm{L} \text { yeast ex- } \\
\text { tract in mineral water }\end{array}$ & $10 \mathrm{~g} / \mathrm{L}$ yeast extract in mineral water ${ }^{\mathrm{a}}$ \\
\hline Inoculation location & $\begin{array}{l}\text { Nutrient injection face-separate inlet line from nutrient- } \\
\text { inlet line }\end{array}$ & Back face to avoid contaminating nutrient-inlet line \\
\hline Inoculation pulse & $\begin{array}{l}\text { Cells suspended in saturation solution and injected as a } \\
90 \mathrm{~min} \text { pulse at } 1 \mathrm{~mL} / \mathrm{min}\end{array}$ & $\begin{array}{l}\text { Cells concentrated by centrifuge, injected, and left in contact } \\
\text { with surface for } 30 \text { min with no flow }\end{array}$ \\
\hline First nutrient & $\begin{array}{l}\text { 7.9 } \mathrm{g} / \mathrm{L} \text { each glucose and fructose with } 10 \mathrm{~g} / \mathrm{L} \text { yeast ex- } \\
\text { tract in mineral water }{ }^{\mathrm{a}}\end{array}$ & $15 \mathrm{~g} / \mathrm{L}$ sucrose with $10 \mathrm{~g} / \mathrm{L}$ yeast extract in mineral water ${ }^{\mathrm{a}}$ \\
\hline Second nutrient & $\begin{array}{l}15 \mathrm{~g} / \mathrm{L} \text { sucrose with } 10 \mathrm{~g} / \mathrm{L} \text { yeast extract in mineral } \\
\text { water }^{\mathrm{a}}\end{array}$ & $\begin{array}{l}\text { Continued using } 15 \mathrm{~g} / \mathrm{L} \text { sucrose with } 10 \mathrm{~g} / \mathrm{L} \text { yeast extract in } \\
\text { mineral } \text { water }^{\mathrm{a}}\end{array}$ \\
\hline Flow rate & $1 \mathrm{~mL} / \mathrm{min}$ (constant) & $0.015 \mathrm{~mL} / \mathrm{min}$ (constant) \\
\hline Space time & $8 \min$ & $26 \min$ \\
\hline Back pressure & $1700 \mathrm{kPa}$ (nominal) & $100 \mathrm{kPa}$ (nominal) \\
\hline Overburden pressure & $6895 \mathrm{kPa}$ & Not applicable \\
\hline Pressure-tap locations & Inlet, $0.625 \mathrm{~cm} ; 3.125 \mathrm{~cm}$, outlet & Inlet and outlet \\
\hline Sampling locations & Effluent line for saccharide and cell count & 30 marked locations for time lapse viewing at $15 \times$ to $100 \times$ \\
\hline
\end{tabular}

${ }^{a}$ Mineral water contains tap water, $\mathrm{NaCl}$, sodium acetate, ascorbic acid, potassium phosphate, and trace minerals (Lappan, 1994). 
determine pore volume. The saturated packed bed was then sterilized in an autoclave and asceptically transferred to a sterile Hassler cell system that is described in detail by Lappan and Fogler (1992). A Hassler cell was used because of the high pressures that were reached during plugging. Pressure taps were located at the inlet, $0.625 \mathrm{~cm}, 3.125 \mathrm{~cm}$, and outlet.

\section{Micromodel Experiments}

Micromodels are two dimensional flow-channel networks etched in glass to simulate fluid flow in porous media. Physical phenomena that occur in the simulated pore throats and bodies during fluid flow are observed through a stereomicroscope at magnifications up to $100 \times$ and recorded with a video camera and recorder. The process used to produce the micromodel is described by Wan et al. (1994). For this work, a triangular network with a coordination number of 6 was used. Pore bodies were $300 \mu \mathrm{m}$ in width with pore throats ranging in width from 30 to $130 \mu \mathrm{m}$ in a heterogeneous mix. The pore volume was $0.39 \mathrm{~mL}$. The flow region was $3.1 \mathrm{~cm}$ in width and $16.2 \mathrm{~cm}$ in length.

The micromodel was mounted in aluminum brackets; Teflon lines and stainless steel fittings were attached to create feed and effluent lines as shown in Figure 1. Check and plug valves were used on these lines to control the direction of flow through the micromodel network. Pressure transducers were placed at the nutrient inlet and outlet of the micromodel and connected to a recorder. Once assembled, the micromodel with the influent and effluent lines was autoclaved as a single closed unit.

\section{Experimental Conditions and Procedure}

The experimental conditions for the packed-bed and micromodel experiments are summarized in Table I. A sterile saturation solution was pumped into the porous media as a back pressure was applied. Back pressure ensured that $\mathrm{CO}_{2}$,

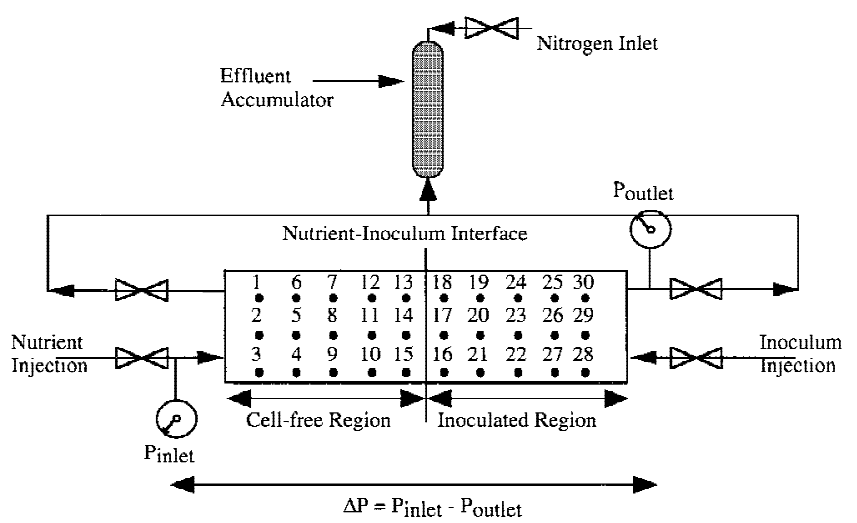

Figure 1. The micromodel system allowed pore-scale visualization of biomass corresponding to changes in measured pressure drop. The 30 locations marked on the micromodel surface were used to map biomass distribution with time in the video recordings. which is generated during metabolism, remained in solution so that a single fluid phase existed throughout the experiment.

After saturation, the porous media was inoculated with exopolymer-free cells in the stationary phase of growth. Stationary growth was known to occur after $24 \mathrm{~h}$ in a batch reactor with the nutrient conditions identified in Table I (Lappan and Fogler, 1994). The cells were harvested from batch reactors and resuspended in nutrient without washing before being injected into the packed bed at a constant flow rate of $1 \mathrm{~mL} / \mathrm{min}$ for $90 \mathrm{~min}$. Effluent cell concentration was measured frequently for the first 135 min to determine the number of cells retained during inoculation. For the micromodel experiment, harvested cells were not resuspended, but the centrifuged cells were injected as a concentrate from the distal end of the micromodel forming an interface as shown in Figure 1. The cells were shut in for $30 \mathrm{~min}$ and then swept away with a $10 \mathrm{~g} / \mathrm{L}$ yeast solution injected through the nutrient inlet.

At $t=0$, nutrient solution was continuously pumped through the porous media at a constant flow rate of $1 \mathrm{~mL} /$ min for the packed-bed experiments and $0.015 \mathrm{~mL} / \mathrm{min}$ for the micromodel experiments. The composition of the nutrient solution used in these experiments is the same as that used by Lappan (1994). Pressure was monitored and recorded at 5-min intervals for the packed-bed experiment at the four pressure-tap locations. Effluent samples were taken at 15-min intervals to measure cell concentration. At 1-h intervals, additional effluent was collected to determine saccharide concentrations as well as cell concentrations. In the micromodel experiments, inlet and outlet pressures were measured at 15-min intervals; no effluent samples were collected. The micromodel was scanned periodically at the 30 locations shown in Figure 1 to observe biofilm development in the pores and overall biomass plug development and propagation along the length of the micromodel.

\section{Assay Methods}

Cell concentration was determined by Coulter counter which has been shown to be useful for providing rapid determination of both cell number and cell size distribution (Kim, 1999). Kim (1999) successfully used this method for L. mesenteroides in the presence and absence of dextran. Saccharide concentration was determined with a reducing sugar assay using dinitrosalicylic acid (Chaplin and Kennedy, 1986).

\section{RESULTS}

A combination of packed-bed and micromodel experiments was used to determine the mechanisms associated with biomass plugging of porous media. This combination provides direct measurement and direct observation. Effluent concentrations of cells and saccharide as well as the pressure drop were measured at different locations along the packed bed. The effluent concentrations of cells and sac- 
charides are used to calculate the amount of biomass grown, released, and retained in the porous media. The pressure drop between pressure taps located along the packed bed was then used to determine regions of greatest plugging, which indicates the distribution of biomass on a macroscopic scale.

Results from micromodel experiments are semiquantitative. The pressure drop across the micromodel is measured directly and the characteristics of the resulting pressure curve are compared to the characteristics of the packed-bed pressure curves. If the pressure drop across the porous media is similar in behavior for the packed bed and micromodel, it can be assumed that the physical phenomena observed directly in the micromodel are also occurring in the packed bed.

In both of these systems, conditions were chosen to isolate the plugging mechanisms associated with exopolymer production. Researchers have observed some reduction of permeability due to cell growth in the absence of exopolymer production when the ratio of grain size (or pore size) to cell size was small and straining occurred (Fontes et al., 1991; Herzig et al., 1970; Kalish et al., 1964; Lappan and Fogler, 1992; MacLeod et al., 1988). Based on the results reported in the literature, a grain size of $300 \mu \mathrm{m}$ was selected for the packed-bed experiment to ensure that straining did not occur. Likewise, the pore throats in the micromodel were large enough to avoid straining. Hence, permeability reduction due to straining was avoided and is not considered here.

The experimental approach was to first carry out packedbed experiments to determine the importance of cell number, exopolymer production, and biomass distribution on plug development and propagation in porous media. Next, micromodel experiments were carried out to directly observe biomass growth and distribution at a pore-scale level. Taken together, the results from these experiments were used to develop a conceptual model describing the mechanisms and physical phenomena associated with biomass plugging of porous media due to exopolymer production.

\section{Pressure Curve Characteristics from Packed Bed Experiments}

There was no measurable increase in pressure drop in the absence of dextran production during the first $34 \mathrm{~h}$ of glucose-fructose injection. As shown in Figure 2, however, there were measurable changes in pressure drop across the packed bed as dextran production proceeded (e.g., during sucrose injection between 34 and $70 \mathrm{~h}$ of total time for saccharide injection). The focus of this article is on the changes in pressure during dextran production where three distinctive regions of the pressure drop curve were identified (see Fig. 2).

- Region 1: Inductions. Between 34 and $36 \mathrm{~h}, 15$ pore volumes of sucrose were injected with no measurable change in pressure drop across the packed bed.

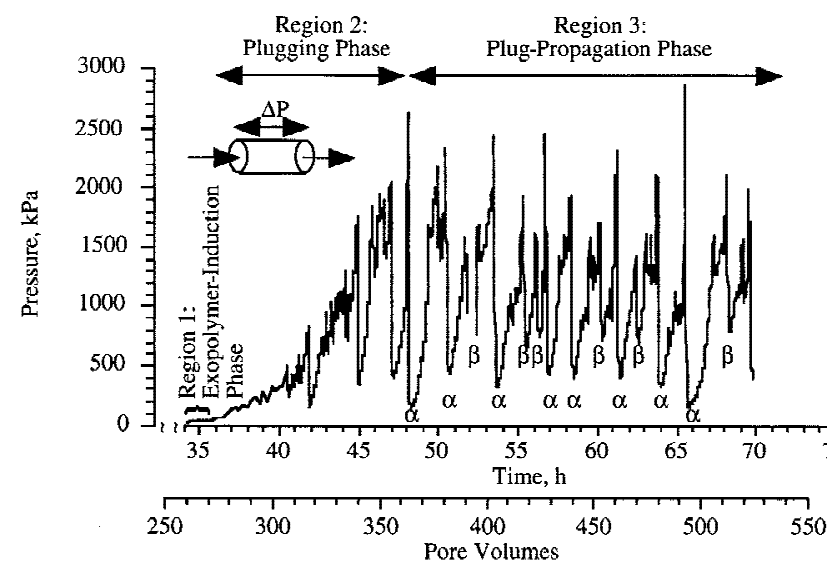

Figure 2. Pressure drop across the packed bed during constant-rate injection of nutrients with $15 \mathrm{~g} / \mathrm{L}$ sucrose from 34 to $70 \mathrm{~h}$. Also shown are the fundamental $(\alpha)$ and secondary $(\beta)$ harmonics from a Fourier-transform analysis.

- Region 2: Onset of pressure drop increase and growth of oscillations. Between 36 and 48 h, an additional 90-pore volumes of sucrose were injected and pressure fluctuation with a net increase in pressure drop across the packed bed occurred as the pressure increased to a maximum value before decreasing sharply. A maximum pressure drop across the packed bed was reached at $48 \mathrm{~h}$ corresponding to three orders of magnitude reduction of permeability $\left(\mathrm{k}_{\text {final }} / \mathrm{k}_{\text {initial }}=0.012\right)$ calculated from Darcy's Law.

- Region 3: Sustained oscillations. Between 48 and 70 h, an additional 165 pore volumes of sucrose were injected. The pressure oscillations continued, but there was essentially no net change in the maximum pressure drop across the packed bed. The average reduction in permeability during this period was $\mathrm{k}_{\text {final }} / \mathrm{k}_{\text {initial }}=0.048$.

For reasons that are discussed in more detail later, Regions 1,2 , and 3 are referred to as the exopolymer induction, plugging, and plug-propagation phases, respectively. These phases are indicated in Figure 2.

\section{Cell Balance and Dextran Production}

It is reasonable to assume that measured changes in pressure drop across the packed bed during sucrose injection were due to some combination of cell number and amount of exopolymer produced. The number of cells retained after inoculation of the packed bed, at the beginning of the sucrose injection that was subsequent to $34 \mathrm{~h}$ of glucosefructose injection, at the onset of plugging, and at the maximum pressure drop across the packed bed can be calculated and compared by using the cell balance shown in Equation (1).

$$
\begin{aligned}
\text { Cells Retained }_{\text {final }}= & \text { Cells Retained } \\
& - \text { Cells Relial }+ \text { Cells Grown }
\end{aligned}
$$


The number of cells retained initially was determined from the effluent cell concentrations during the 90-min inoculation pulse and was found to be $0.03 \times 10^{12} \pm 0.06 \times 10^{12}$ cells. There was no measurable cell growth in the inoculum during the inoculation. The number of cells grown during nutrient injection was determined by using the effluent saccharide concentrations and cell yields that had been determined by Lappan (1994). These cell yields were $1.1 \times 10^{11}$ cells/g glucose, $9.9 \times 10^{10}$ cells/g fructose, and $6.7 \times 10^{10}$ cells/g sucrose. Cell yields for the monosaccharides are very similar. The lower cell yield for sucrose is likely due to use of glucose units from hydrolyzed sucrose to form dextran rather than new cells. Effluent cell concentrations were used to determine number of cells released. Cells grown, released, and retained with time of nutrient injection are shown in Figure 3.

In addition to calculating number of cells retained, the amount of exopolymer produced at the onset of plugging and at the maximum pressure drop across the packed bed can also be calculated and compared. These calculations were made by using effluent saccharide concentrations and a dextran yield of $0.09 \mathrm{~g}$ glucose as dextran/g sucrose determined by Lappan (1994). Detailed discussions of the relative importance of cell retention and dextran production as related to the three pressure phases are presented in the following sections.

\section{Cell Retention and Dextran Production During the Exopolymer-Induction Phase}

The exopolymer-induction phase began with the switch to sucrose nutrient and ended at the onset of plugging as shown in Figure 2. A cell balance was done to determine whether an increase in the number of cells retained or exopolymer produced or both caused the onset of plugging. Based on the cell balance, there was no change in number of cells retained during the exopolymer-induction phase. At the end of the glucose-fructose injection phase and beginning of the exopolymer-induction phase, there were $1 \times 10^{12}$

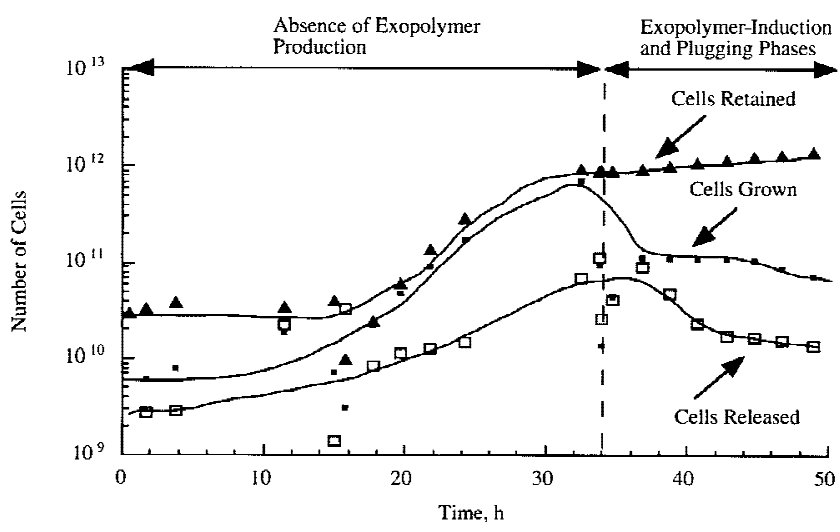

Figure 3. Cell growth, release, and retention during constant-rate injection of nutrients with $7.9 \mathrm{~g} / \mathrm{L}$ each glucose and fructose from 0 to $34 \mathrm{~h}$ and $15 \mathrm{~g} / \mathrm{L}$ sucrose from 34 to $70 \mathrm{~h}$. $\pm 0.6 \times 10^{12}$ cells retained in the porous media. At the end of the exopolymer-induction phase, there were still $1 \times 10^{12}$ $\pm 0.7 \times 10^{12}$ cells retained, because number of cells grown was equal to number of cells released.

Even though the total number of cells retained did not change statistically, the amount of exopolymer did change. The amount of dextran produced at the end of the exopolymer-induction phase was calculated as $0.2 \mathrm{~g}$ glucose as dextran. It was previously shown that $24 \%$ of dextran produced in this manner was water-insoluble (Lappan and Fogler, 1994). It can be surmised that this amount of dextran was sufficient to alter biomass distribution in the packed bed to initiate plugging. Further evidence of the role of dextran was collected from the micromodel experiment and will be discussed later.

\section{Cell Retention and Dextran Production During the Plugging Phase}

Between 36 and $48 \mathrm{~h}$, the pressure drop across the packed bed increased steadily due to plugging until a maximum pressure drop was reached at $48 \mathrm{~h}$ (see Fig. 2). A comparison of number of cells retained and dextran produced at the beginning and end of the plugging phase provides insight into the importance of each as biomass plugging proceeded. As can be seen in Figure 3, the rate of cells grown between 36 and $48 \mathrm{~h}$ of sucrose injection is less than during the rapid growth that occurred between 18 and $34 \mathrm{~h}$ of glucose and fructose injection. Additionally, the average rate of cells released is slightly less between 36 and $48 \mathrm{~h}$ compared to the period between 18 and $34 \mathrm{~h}$ of glucose and fructose injection (see Fig. 3). Results from previous work have indicated that exopolymers may play a key role in surface adhesion that would account for this reduction in cell release during dextran production (Allison and Sutherland, 1987; Fletcher and Floodgate, 1973; Sutherland, 1983; van Loosdrecht et al., 1987). The overall result was that there was an increase of $50 \%$ in number of cells retained (i.e., 1.5 $\times 10^{12} \pm 0.7 \times 10^{12}$ cells at $48 \mathrm{~h}$ ) as the maximum pressure drop across the packed bed was reached, while the amount of dextran correspondingly increased $400 \%$ to 0.8 g glucose as dextran at $48 \mathrm{~h}$. These results indicate that permeability reduction during the plugging phase is strongly dependent on the increased amount of dextran produced and not on a significant increase in the number of cells retained once a sufficient number of cells are retained in the porous media. Under these experimental conditions, $1 \times 10^{12}$ cells corresponding to a concentration of $1.3 \times 10^{11}$ cells $/ \mathrm{mL}$ of pore volume was sufficient.

\section{Biomass Distribution During Exopolymer- Induction, Plugging, and Plug-Propagation Phases}

Before discussing the total number of cells retained and amount of dextran produced during the plug-propagation phase, it is important to understand the distribution of biomass as plugging proceeds. From pressure measurements at 
each of the pressure taps, the distribution of biomass can be inferred. In Figure 4, the pressure drop across the packed bed determined at each of the pressure-tap locations is shown for the exopolymer-induction and plugging phases. Although the onset of the plugging phase occurred at $36 \mathrm{~h}$ at the inlet-pressure tap, it occurred later at the downstream pressure taps, i.e., at $37 \mathrm{~h}$ for $\mathrm{P}_{1}$, and at $41.5 \mathrm{~h}$ for $\mathrm{P}_{2}$. This result is an indication that the biomass plug developed in the direction of flow during the plugging phase.

The pressure decrease along the length of the packed bed can be used to further determine the distribution of biomass during changes in pressure. The pressure drop per unit length $(\Delta \mathrm{P} / \mathrm{L})$ is inversely proportional to permeability; hence, a high $\Delta \mathrm{P} / \mathrm{L}$ corresponds to regions within the packed bed that have low permeability. The relationship between $\Delta \mathrm{P} / \mathrm{L}$ for the full length of the packed bed and the first section of the packed bed, $\Delta \mathrm{P}_{1} / \mathrm{L}_{1}$, is shown in Figure 5. The pressure drop for $\Delta \mathrm{P}_{1} / \mathrm{L}_{1}$ was greater than $\Delta \mathrm{P} / \mathrm{L}$ for the full length of the packed bed during the entire period of sucrose injection. This finding indicates that the biomass plug was most dense and the permeability the lowest in the first section of the packed bed throughout the experiment, a result that is consistent with findings of other researchers (Geesey et al., 1987; Vandevivere and Baveye, 1992).

A similar analysis of the pressure drop per unit length for the second $\left(\Delta \mathrm{P}_{2} / \mathrm{L}_{2}\right)$ and the third $\left(\Delta \mathrm{P}_{3} / \mathrm{L}_{3}\right)$ sections of the packed bed was carried out. In contrast to the $\Delta \mathrm{P} / \mathrm{L}$ in the first section of the packed bed, the relationship of $\Delta \mathrm{P}_{2} / \mathrm{L}_{2}$ and $\Delta \mathrm{P}_{3} / \mathrm{L}_{3}$ changed with time. Initially, the pressure drop in the second section was greater than that in the third section, e.g., during the exopolymer-induction and plugging phases between $34 \mathrm{~h}$ and $48 \mathrm{~h}$. This result indicates that the biomass plug was growing in the direction of flow during these phases.

However, $\Delta \mathrm{P}_{3} / \mathrm{L}_{3}$ was greater than $\Delta \mathrm{P}_{2} / \mathrm{L}_{2}$ after the significant decrease in pressure drop across the packed bed at $48 \mathrm{~h}$ that marked the onset of the plug-propagation phase. This rapid change in the relative magnitude of pressure drop

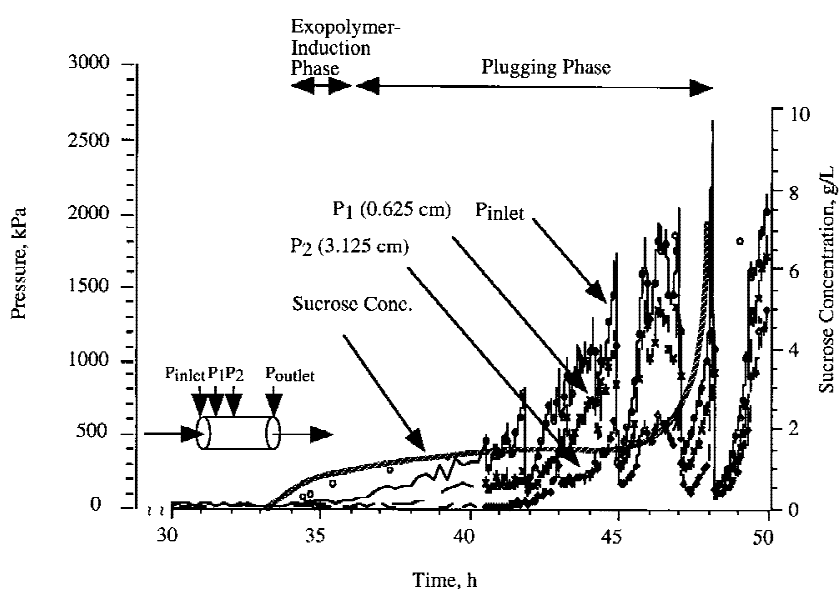

Figure 4. Comparison of pressure drop at all pressure taps along packedbed and effluent saccharide concentrations during exopolymer induction and plugging phases.

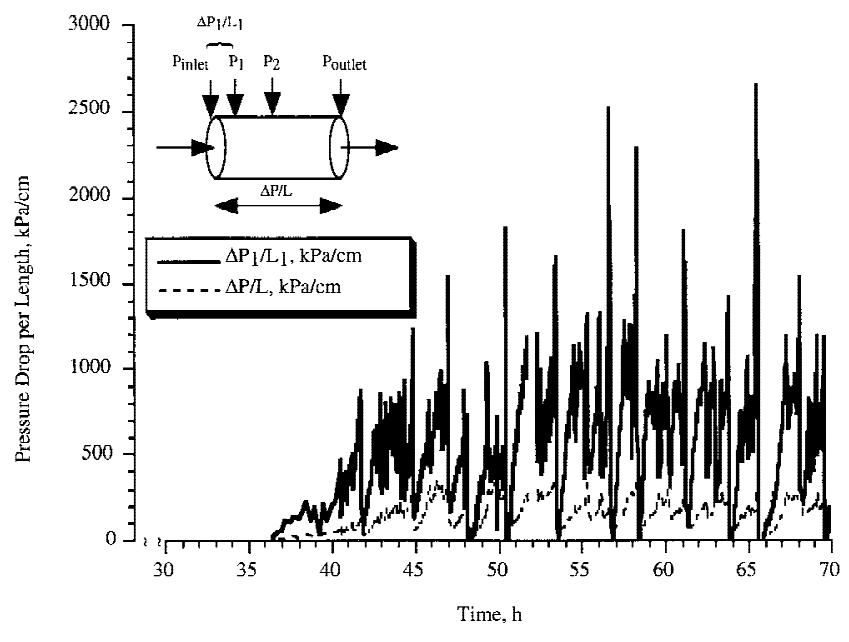

Figure 5. Comparison of pressure drop per unit length in the first section of the packed bed, $\Delta \mathrm{P}_{1} / \mathrm{L}_{1}$, and $\Delta \mathrm{P} / \mathrm{L}$ for the full length of the packed bed during sucrose nutrient injection between 34 and $70 \mathrm{~h}$.

per unit length between these two pressure taps indicates a significant physical shift in the location of biomass in these downstream segments at $48 \mathrm{~h}$. This relocation is likely due to hydrodynamic causes such as sloughing of biomass located upstream and mechanical recapture of biomass downstream. Further, an abrupt increase in the effluent saccharide concentration shown in Figure 4 began at $46 \mathrm{~h}$ as the peak pressure drop was approached and continued as the maximum pressure drop across the packed bed was reached at 48 $h$. The combination of physical shifting of biomass and an abrupt increase in effluent saccharide concentration suggests that a breakthrough flow channel formed and that the sucrose nutrient followed this channel with less dispersion.

As the plug-propagation phase continued, the magnitude of the plug in the second and third sections changed again. Between 56 and $64 \mathrm{~h}$, the pressure drop per unit length in the second section was greater than in the third section. At $64 \mathrm{~h}$, however, biomass again shifted and the pressure drop per unit length in the third section was greater than in the second section. It can be concluded from these results that biomass develops in the direction of nutrient flow during the plug-propagation phase. It can be surmised that this propagation is due to both growth and dextran production and hydrodynamic redistribution of biomass due to sloughing and mechanical recapture. Confirmation of these conclusions was sought with the micromodel experiment that will be discussed later in this article.

\section{Cell Retention and Dextran Production During the Plug-Propagation Phase}

Evaluation of $\Delta \mathrm{P}_{2} / \mathrm{L}_{2}$ and $\Delta \mathrm{P}_{3} / \mathrm{L}_{3}$ during the pressure oscillations in the plug-propagation phase shows that biomass increased in some sections of the packed bed as nutrient injection continued. An increase in biomass corresponds to the pressure increases measured during the pressure oscillations. The question is whether the pressure peaks during 
oscillation were due primarily to an increase in number of cells retained or dextran produced or both. To determine this relationship, a Fourier transform analysis of packed-bed pressure data was conducted. The pressure data between 48 and $70 \mathrm{~h}$ were used in this analysis to determine the frequency of the pressure oscillations and relate this frequency to in situ cell retention and exopolymer production. It was determined that a fundamental harmonic occurred at $2.6 \mathrm{~h}$ (or 19.5 pore volumes of sucrose) and a secondary harmonic occurred at $1.6 \mathrm{~h}$ (or 12 pore volumes of sucrose).

By using the average sucrose consumed during sucrose injection along with cell and dextran yields, a steady-state rate of cell growth and dextran production were calculated as $5 \times 10^{10}$ cells $/ \mathrm{h}$ and $0.07 \mathrm{~g}$ glucose as dextran $/ \mathrm{h}$, respectively. The fundamental harmonic of $2.6 \mathrm{~h}$ corresponds to 1 $\times 10^{11}$ cells grown and $0.2 \mathrm{~g}$ glucose as dextran produced during the oscillations. The low fraction (i.e., 0.1) of cells grown compared to cells retained suggests that cell growth is not the driving factor behind the pressure increases measured during pressure oscillations. The amount of dextran produced during a fundamental harmonic, however, is the same as that produced during the exopolymer-induction phase. This amount of dextran was enough to induce plugging, suggesting that the amount of dextran produced is the more important phenomenon associated with pressure oscillations.

Additionally, a relationship exists between the harmonic and the magnitude of minimum pressure drop across the packed bed reached during a pressure oscillation. As shown in Figure 2, the fundamental harmonic at $2.6 \mathrm{~h}$ relates to deep pressure valleys where the pressure drop across the packed bed at these minimum points ranges from 120 to 430 $\mathrm{kPa}$. For the secondary harmonic, higher minimum pressures drops across the packed bed are included which range from 670 to $750 \mathrm{kPa}$ (see Fig. 2). These minimums have been related to possible channel breakthroughs where the pressure increased to such an extent that the yield stress of the plug was exceeded and the biomass plug was moved out of the channel resulting in flow and a drop in pressure. It can be believed that the pressure minimums are related to the flow-channel length. Those flow channels formed at 2.6-h intervals may be more extensive, probably spanning the full length of the packed bed. The flow channels formed at 1.6 $\mathrm{h}$ may be localized channels that provide lesser relief to flow restrictions. These postulations will be expanded in the section below.

\section{Results of Micromodel Experiments}

Based on the results of the packed-bed experiment, micromodel experiments were carried out to observe biomass distribution of cells in the pore spaces under exopolymerproducing conditions that lead to biomass plugging. In addition, confirmation of biomass yielding to form flow channels during pressure-drop minimums and an increase in biomass during increases in pressure drop was needed by direct observation.
The pressure drop across the micromodel during sucrose injection was measured to determine pressure-curve characteristics. The same three regions of the pressure curve observed during exopolymer production in the packed bed were also observed in this micromodel experiment as shown in Figure 6. The exopolymer-induction phase occurred between 0 and $19 \mathrm{~h}$ after 44 pore volumes of sucrose were injected. The induction phase for this micromodel experiment was longer and required more pore volumes of nutrient than the packed-bed experiment due to the lower number of cells present in the micromodel at the time sucrose injection was initiated. This result highlights that the amount of dextran produced, which was found in the packed-bed experiment to be a key mechanism in this phase, is a function of cell number and that a sufficient number of cells must be retained to produce enough dextran to initiate plugging. The plugging phase occurred between 19 and 25 $\mathrm{h}$ as constant-rate nutrient injection continued for an additional 14 pore volumes. There were no pressure oscillations measured during the plugging phase in the micromodel due to the simpler geometry of the porous media. Subsequent to the plugging phase, pressure oscillations without a net change in maximum pressure drop across the micromodel were measured for the remainder of the experiment, marking the plug-propagation phase. The similarity in the pressure drop curves from the packed-bed and micromodel experiments indicates that the physical phenomena observed in the micromodel can be related to the packed-bed results.

To relate the physical phenomena occurring within each of these pressure phases, the biomass in the micromodel was observed at several locations. The biomass distribution at one of these locations is shown in Figure 7 for key times during changes in pressure drop shown in Figure 6 (see cross reference between Figs. 6 and 7). In Figure 7a, biomass at location 17 near the nutrient-inoculum interface is shown at $14 \mathrm{~h}$ of sucrose injection. (See Fig. 1 for locations in micromodel.) The noncontiguous colonies of cells and dextran are representative of biomass distribution through-

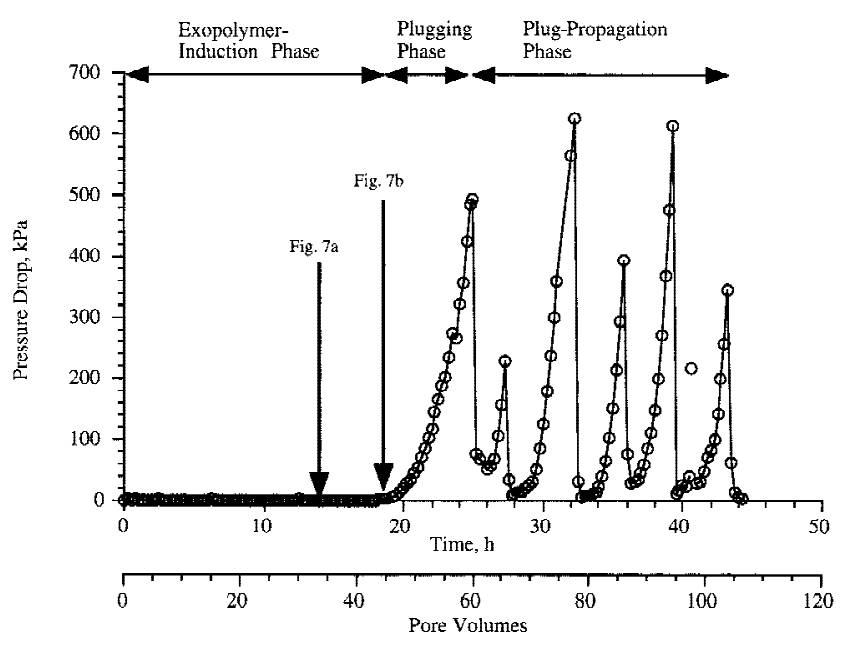

Figure 6. Pressure drop across micromodel during constant-rate injection of nutrient with $15 \mathrm{~g} / \mathrm{L}$ sucrose. 


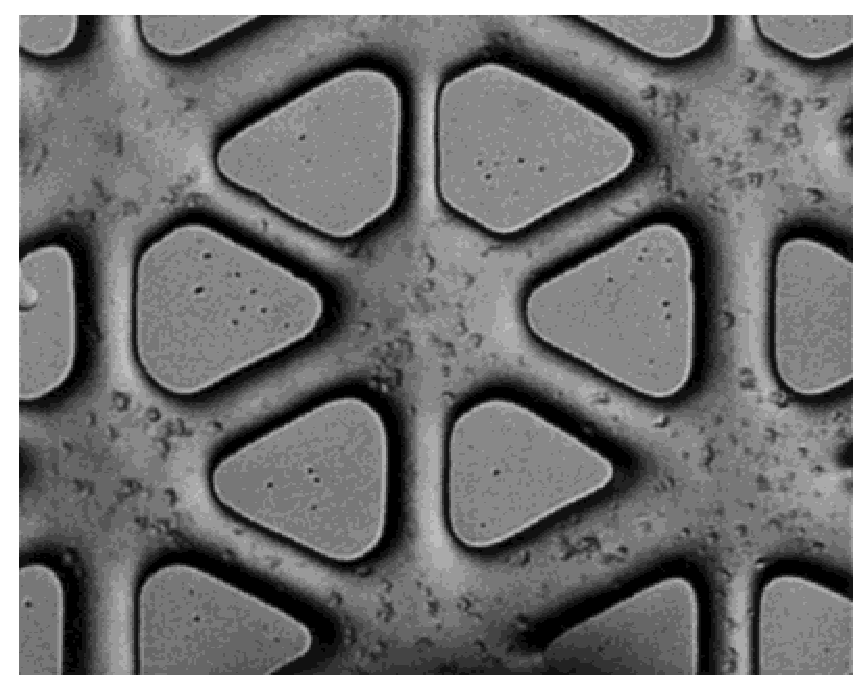

(a)

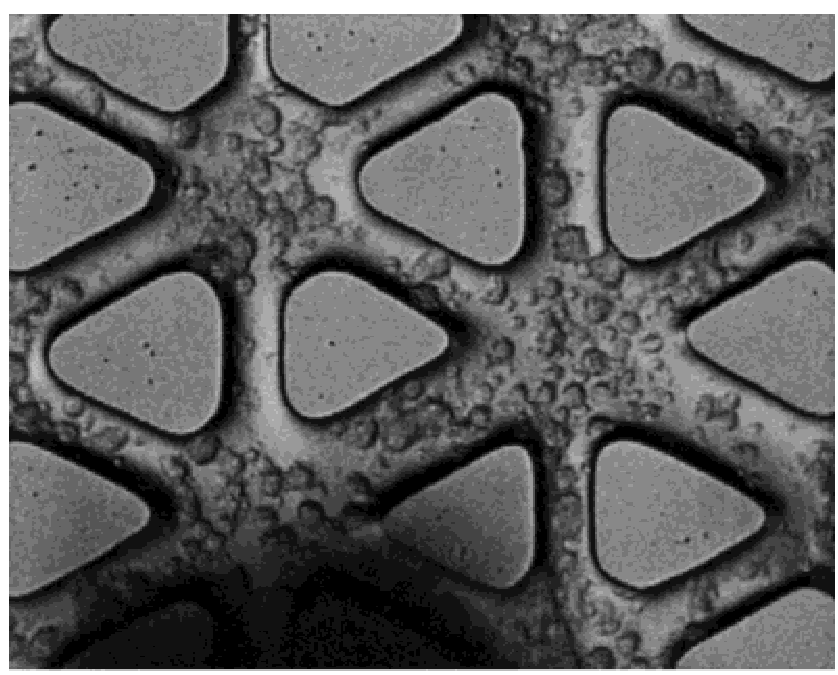

(b)

Figure 7. Biomass distribution (a) during exopolymer-induction phase at location 17 after $14 \mathrm{~h}$ of sucrose nutrient injection (100x magnification), and (b) during transition from induction to plugging phase at location 17 after $18.5 \mathrm{~h}$ of sucrose nutrient injection (100× magnification).

out the micromodel in the early part of the exopolymerinduction phase. As can be seen, the biomass has not yet filled the pore volume; flow channels comprised of connecting pore throats that are relatively free of biomass still exist. As a result, nutrient disperses and flows through the porous media without a measurable change in pressure.

By $18.5 \mathrm{~h}$, a transition between the induction and plugging phase was beginning as can be seen by the onset of an increase of pressure drop across the micromodel shown in Figure 6. At $18.5 \mathrm{~h}$, the colonies of cells and dextran were becoming contiguous and beginning to fill the pore spaces at location 17, as shown in Figure $7 \mathrm{~b}$. As plugging proceeded, a dense growth of biomass developed and extended for a depth of $2 \mathrm{~cm}$ from the nutrient-inoculum interface, creating the first of a series of biomass plugs in the micromodel. Under these conditions, convective flow within the biomass plug occurred through the biofilm. Recent studies using confocal laser microscopy have provided new information on biofilm structures that suggest a primitive circulatory system exists, comprising water channels around the base of biofilm structures (Costerton, 1999). It has been shown through the use of nuclear magnetic resonance imaging that convective flow occurs within these water channels (Costerton et al., 1994). Resistance to flow through these biofilm water channels, however, was greater than through the porous media flow channels observed at $14 \mathrm{~h}$, resulting in the increased pressure drop across the micromodel during the plugging phase.

The sharp drop in pressure drop across the micromodel at 25 h shown in Figure 6 corresponded to the formation of a breakthrough flow channel in this first biomass plug near location 21. Just downstream of the first biomass plug and at the end of the breakthrough flow channel (i.e., location 22), a large amount of biomass was also removed during this time. Flow channels within and downstream of this first plug rather than water channels within the biomass dominated convective flow at the minimum pressure drop across the packed bed. Two hours later, a second maximum pressure drop across the micromodel, which was smaller in magnitude, was being approached as can be seen in Figure 6. It corresponded to healing (i.e., channel refilling with biomass) of the initial breakthrough flow channel. As the channel healed, convective flow was dominated once again by flow within the water channels of the biofilm.

Further review of the video recordings showed that a second breakthrough flow channel occurred and corresponded to a second minimum pressure drop across the micromodel. It was followed by the third maximum pressure drop across the micromodel, which was about the same magnitude as the first maximum, that corresponded to development of another biomass plug downstream of the first plug. Hence, the characteristic pressure curve can be related to the sequential development of biomass plugs in the direction of flow followed by breakthrough of these plugs. Further, pressure oscillations can be related to the alternation of convective flow through flow channels within the porous media and water channels within the biofilm as plug development and breakthrough occur.

\section{DISCUSSION}

The results from the packed-bed and micromodel experiments elucidate the key mechanisms and physical phenomena resulting in biomass plug development and propagation in porous media (see Fig. 8). In modeling the exopolymerinduction phase, start with the inoculated porous media as sucrose injection begins and end with the onset of plugging. The amount of exopolymer produced as a function of cell number is the key mechanism. In this phase, the cells are evenly distributed throughout the porous media initially (see Fig. 8a). Supporting evidence for this profile comes from 


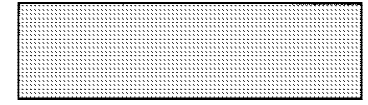

Cross-sectional View of Porous Media

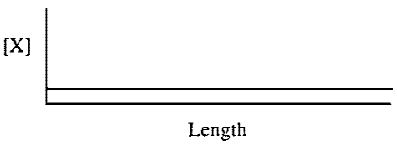

\section{(a)}
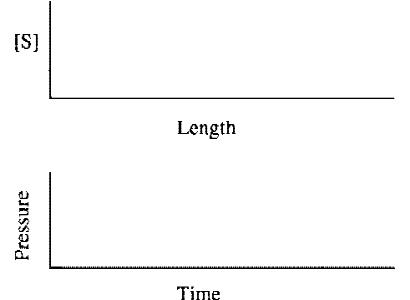

End of Plugging Phase

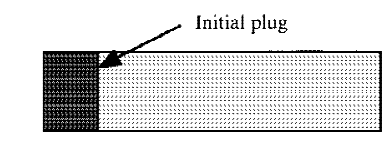

Cross-sectional View of Porous Media

$[\mathrm{X}]$

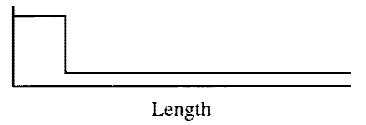

(c)

Second Plug during Plug Propagation Phase

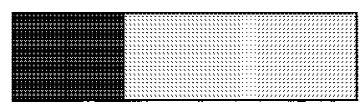

Cross-sectional View of Porous Media

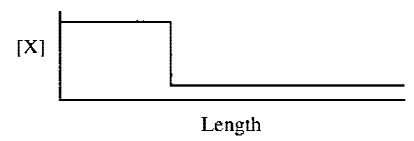

(e)
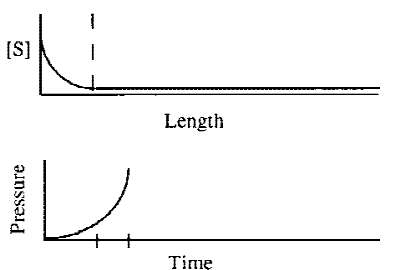

Time

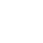

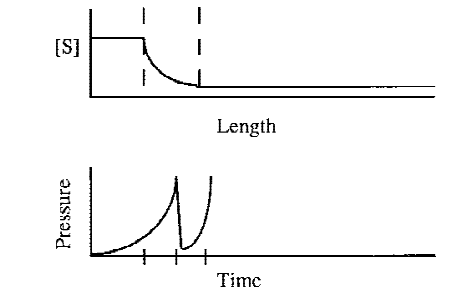

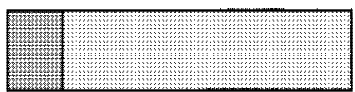

Cross-sectional View of Porous Media

$[\mathrm{X}]$

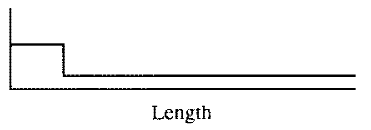

(b)

Onset of Plug Propagation Phase

)
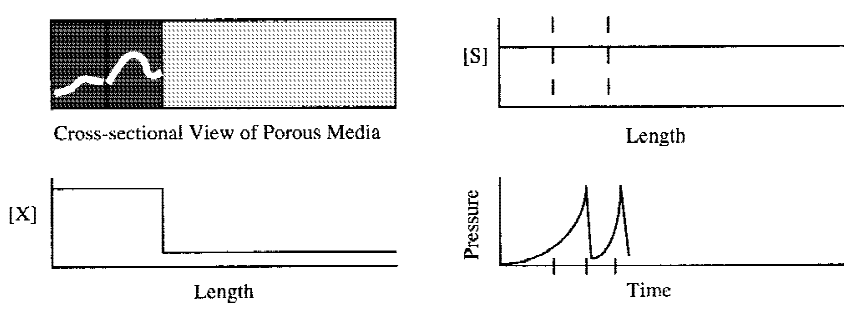

(f)
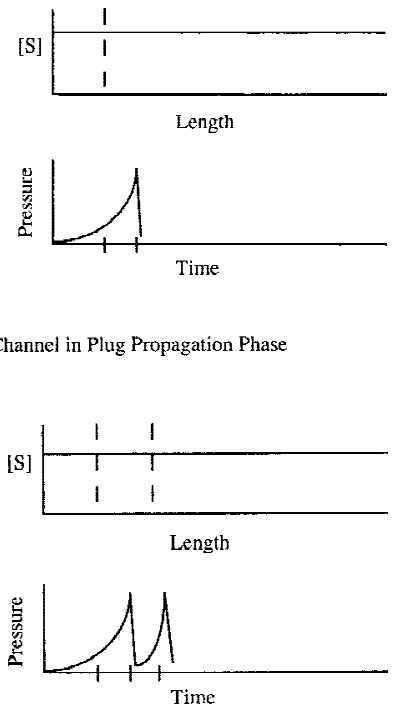

(d)
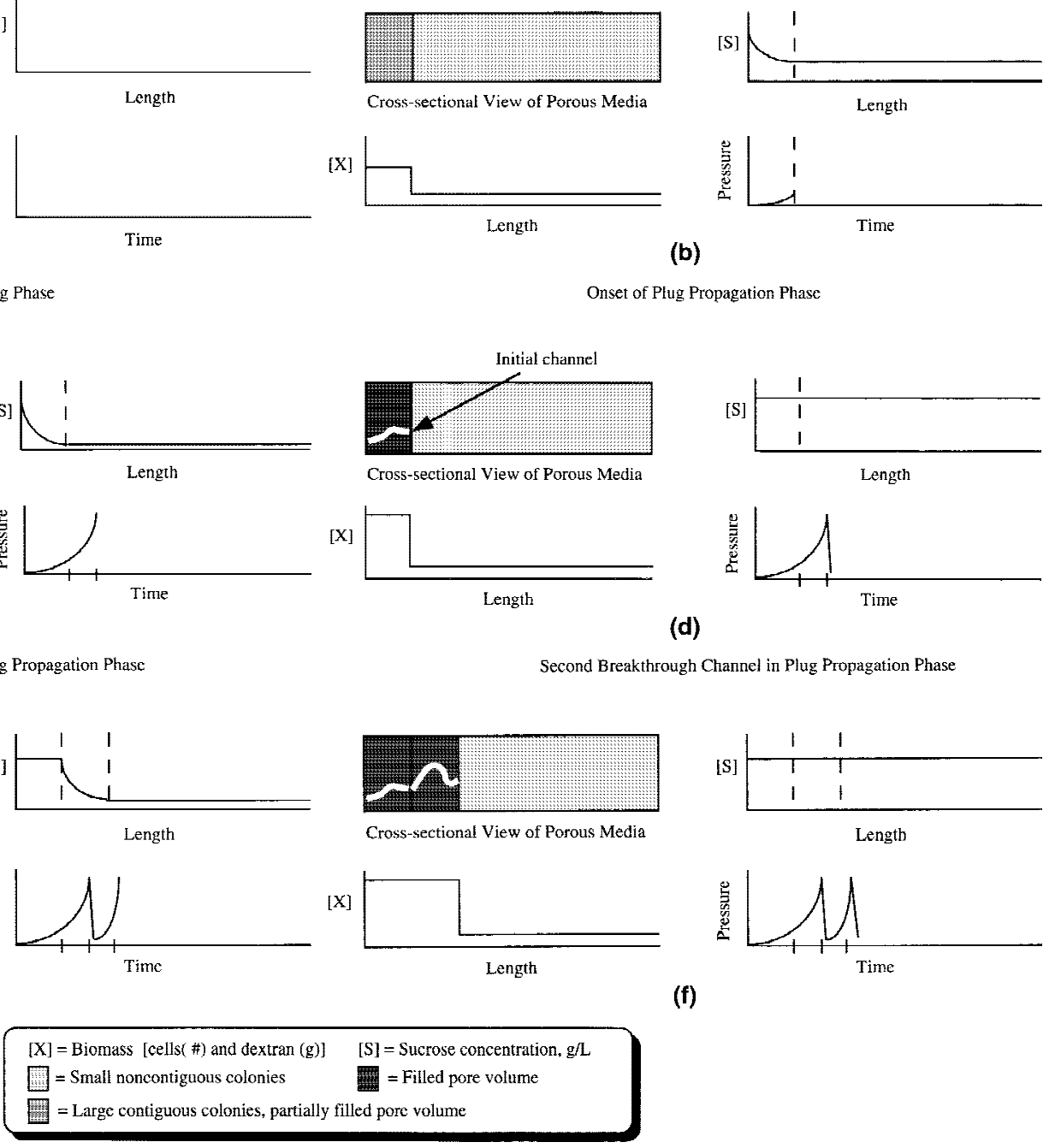

Figure 8. Summary description of plug development and propagation at (a) end of inoculation and beginning of exopolymer-induction phase, (b) end of exopolymer-induction phase, (c) end of plugging phase, (d) onset of plug-propagation phase, (e) second plug formation during plug-propagation phase, and (f) second breakthrough channel in plug-propagation phase.

both experiments. In the packed bed, effluent cell concentration was equal to influent cell concentration after 1.25 pore volumes of inoculum indicating that exopolymer-free cells readily transported through the porous media. Hence, a constant cell profile at $t=0$ is plausible. Further, a constant profile of cells was observed initially in the micromodel, a section of which is shown in Figure 7a. Correspondingly, it can be surmised that the sucrose gradient follows the biomass distribution and also has a constant profile. There is no change in pressure drop across the micromodel due to low cell and dextran concentrations in the porous media at this point.

The onset of an increase in pressure drop across the porous media is the transition between the exopolymerinduction phase and the plugging phase. Here the profile changes and a biomass gradient begins to form. The region of increasing biomass density is at the nutrient inlet as shown in Figure 8b. This biomass gradient was observed and recorded visually from the micromodel experiment as shown in Figure $7 \mathrm{~b}$ and measured directly as $\Delta \mathrm{P} / \mathrm{L}$ in the packed bed as shown in Figure 5. Most likely a sucroseconcentration gradient begins to develop due to a higher rate of nutrient consumption in the vicinity of the greatest amount of biomass. Although the sucrose gradient could not be measured directly in the experiments, effluent saccharide data did indicate that rapid growth resulted in a rapid decrease in effluent saccharide concentration in the packedbed experiment.

At the end of the plugging phase, the first maximum pressure drop across the porous media is reached as pore space in the region of the first plug is filled with biomass. Like the exopolymer-induction phase, the amount of dextran produced as a function of cell number is the key mechanism in the plugging phase. Dextran production allows adhesion of the biomass and filling of the pore spaces. This filling continues until a maximum density of the biomass 
develops in the region of the first plug located near the nutrient inlet as shown in Figure 8c. Such a plug was observed directly in the micromodel experiment. Additionally, the $\Delta \mathrm{P} / \mathrm{L}$ data from the packed bed confirmed this observation. At the end of the plugging phase, the sucroseconcentration gradient becomes more pronounced as the biomass gradient becomes more pronounced.

At the beginning of the plug-propagation phase, a minimum pressure drop across the porous media occurs abruptly as a breakthrough flow channel (shown in Fig. 8d) is formed. This physical phenomenon was confirmed in the micromodel experiment where it was observed that the channel formed due to biomass yielding. Specifically, as the maximum pressure drop across the micromodel was approached, local shearing of the contiguous biomass colonies was observed. The sheared colonies were not immediately swept away; instead, they packed tightly in the pore bodies and throats from which they were sheared. At a maximum pressure drop across the micromodel, this packed biomass yielded much like a Bingham plastic and, subsequently, flowed out of the breakthrough channel. Hence, yield stress is an additional mechanism that is key to propagation of plugs downstream of the nutrient inlet.

Convective flow of the nutrient follows the less-resistantflow channel through the biomass plug. Consequently, the concentration of sucrose in the nutrient is temporarily higher and has a constant profile in the porous media as shown in Figure 8d. As a result, biomass downstream of the first plug is exposed to higher concentrations of sucrose than before the flow-channel formation. This higher sucrose concentration after flow-channel formation was confirmed by looking at the abrupt increase of effluent sucrose concentration from the packed bed at $48 \mathrm{~h}$ which corresponded to the abrupt decrease in pressure drop across the packed bed (see Fig. 4).

With a higher sucrose concentration, cells along the flow channel and in the region just downstream of the first plug are now stimulated. New biomass fills the channel and develops a second plug, corresponding to the second maximum pressure drop across the porous media reached during the plug-propagation phase (see Fig. 8e). An increase of biomass in downstream segments in the packed bed was observed from the $\Delta \mathrm{P} / \mathrm{L}$ data. Healing of the breakthrough flow channel was observed directly in the micromodel experiment. Further, review of the video record of the micromodel experiment revealed development of sequential biomass plugs downstream of the previous plugs that corresponded to maximum pressure drops across the micromodel shown in Figure 6. As during development of the first plug, a sucrose gradient develops in the porous media during development of the second plug. It is shifted downstream, however, to the region of the second plug where most new cell growth and dextran production is occurring.

As a second maximum pressure drop across the porous media is reached, biomass yields and a second channel breaks through the first two plugs with a corresponding shift to a constant sucrose profile. This repeating sequence of plug development, followed by channel breakthrough and accelerated downstream-biomass growth to develop a new plug explains the physical phenomena that are occurring during the pressure oscillations. Furthermore, it confirms that biomass plugging is being propagated in the direction of flow during these oscillations (see Fig. 8f).

\section{CONCLUSIONS}

The combination of packed-bed and micromodel experiments was used to elucidate the key mechanisms and physical phenomena that contribute to biomass plugging of porous media. Several conclusions can be drawn from the results:

- Biomass plugging mechanisms correspond to three distinct regions of the pressure-time trajectories. These regions are referred to as the exopolymer-induction phase, the plugging phase, and the plug-propagation phase.

- The primary mechanism associated with the exopolymerinduction phase is the amount of exopolymer produced; a sufficient number of cells must be retained due to inoculation, cell growth, and cell release to produce enough dextran. The key physical phenomenon is development of noncontiguous colonies throughout the porous media that do not significantly reduce the pore volume.

- The primary mechanism associated with the plugging phase is production of exopolymer; the key physical feature is a reduction of pore volume in the vicinity of the first plug near the nutrient-inoculation interface that leads to an increase in the pressure drop across the porous media. There is also a shift of convective flow from flow channels within the porous media to water channels within the biofilm in the plugged portion of the porous media.

- The primary mechanisms associated with the plugpropagation phase are yield stress and exopolymer production; the key physical features are pressure oscillations resulting from sequential development of biomass plugs in the direction of flow followed by periodic plug breakthroughs. Shifting of convective flow between flow channels within the porous media and water channels within the biofilm in the plugged portion of the porous media is ongoing.

These are new findings that provide a basis for designing selective plugging systems that can penetrate deeply into the porous media; this is especially important for the bacterial profile modification application.

\section{References}

Allison DG, Sutherland IW. 1987. The role of exopolysaccharides in adhesion of freshwater bacteria. J Gen Microbiol 133:1319-1327.

Chaplin MF, Kennedy JF. 1986. Carbohydrate analysis: a practical approach. Oxford: IRL Press Limited. 
Costerton JW. 1999. Introduction to biofilms. Int J Antimicrob Agents 11:217-221.

Costerton JW, Lewandowski Z, DeBeer D, Caldwell D, Korber D, James G. 1994. Biofilms, the customized microniche. J Bacteriol 176: 2137-2142.

Fletcher M, Floodgate GD. 1973. An electron-microscope demonstration of an acid polysaccharide involved in the adhesion of a marine bacterium to solid surface. J Gen Microbiol 74:325-334.

Fontes DE, Mills AL, Hornberger GM, Herman JS. 1991. Physical and chemical factors influencing transport of microorganisms through porous media. Appl Environ Microbiol 57:2473-2481.

Geesey GG, Mittelman MW, Lieu VT. 1987. Evaluation of slimeproducing bacteria in oil field core flood experiments. Appl Environ Microbiol 53:278-283.

Herzig JP, LeClerc DM, Le Goff P. 1970. Flow of suspensions through porous media. Ind Eng Chem 62:8-35.

Jack TR, DiBlasio E. 1985. Selective plugging for heavy oil recovery. In: Zajic JE, Donaldson EC, editors. Microbes and oil recovery, Vol. 1. El Paso, TX: Bioresources Publications. p 205-212.

Jack TR, DiBlasio E, Thompson BG, Ward V. 1983. Bacterial systems for selective plugging in secondary oil production. Preprints, Symposia, Division of Petroleum Chemistry. Am Chem Soc 27:773-784.

Jack TR, Shaw JC, Wardlaw NC, Costerton JW. 1989. Microbial plugging in enhanced oil recovery. In: Donaldson EC, Chilingarian GV, Yeh TF, editors. Microbial enhancement of oil recovery. Amsterdam: Elsevier. p 125-149.

Jack TR, Stehmeier LG, Islam MR, Ferris FG. 1991. Microbial selective plugging to control water channeling. In: Donaldson EC, editor. Microbial enhancements of oil recovery—Recent advances. Amsterdam: Elsevier. p 433-440.

Jeanes A, Haynes WC, Wilham CA, Rankins JC, Melvin EH, Austin MJ, Cluskey JE, Fisher BE, Tsuchiya HM, Rist CE. 1954. Characterization and classification of dextrans from ninety-six strains of bacteria. J Am Chem Soc 76:5041-5052.

Jenneman GE, Knapp RM, McInerney MJ, Menzie DE, Revus DE. 1984 Experimental studies of in-situ microbial enhanced oil recovery. Soc Pet Eng J 24:33-37.

Kalish PJ, Stewart JA, Rogers WF, Bennett EO. 1964. The effect of bacteria on sandstone permeability. J Petr Technol 222:805-814.
Kim DS. 1999. Biomass evolution in porous media under bacterial starvation conditions. Ph.D. thesis, University of Michigan, Ann Arbor.

Lappan RE. 1994. Reduction of porous media permeability from in situ bacterial growth and polysaccharide production. Ph.D. thesis, University of Michigan, Ann Arbor.

Lappan RE, Fogler HS. 1992. Effect of bacterial polysaccharide production on formation damage. SPE Prod Eng 7(2):167-171.

Lappan RE, Fogler HS. 1994. Leuconostoc mesenteroides growth kinetics with application to bacterial profile modification. Biotechnol Bioeng 43:865-873.

Lappan RE, Fogler HS. 1996. Reduction of porous media permeability from in situ Leuconostoc mesenteroides growth and dextran production. Biotechnol Bioeng 50:6-15.

MacLeod FA, Lappin-Scott HM, Costerton JW. 1988. Plugging of a model rock system by using starved bacteria. Appl Environ Microbiol 54: $1365-1372$.

Mitchell R, Nevo Z. 1964. Effect of bacterial polysaccharide accumulations on infiltration of water through sand. Appl Environ Microbiol 12:219-223.

Parlie JA, Stepp AK, Evans DB, Bryant RS, Jenneman GE. 1998. Transport and stability of polymer-producing bacteria in porous media. Soc Petr Eng 39670:173-182.

Raiders RA, Freeman DC, Jenneman GE, Knapp RM, McInerney MJ, Menzie DE. 1985. The use of microorganisms to increase the recovery of oil from cores. Soc Petr Eng 14336:1-5.

Shaw JC, Bramhill B, Wardlaw NC, Costerton JW. 1985. Bacterial fouling in a model core system. Appl Environ Microbiol 49:693-701.

Sutherland IW. 1983. Microbial exopolysaccharides-Their role in microbial adhesion in aqueous systems. CRC Crit Rev Microbiol 10: 173-201.

Vandevivere P, Baveye P. 1992. Effect of bacterial extracellular polymers on the saturated hydraulic conductivity of sand columns. Appl Environ Microbiol 58:1690-1698.

van Loosdrecht MCM, Lyklema J, Norde W, Shraa G, Zehnder AJB. 1987. The role of bacterial cell wall hydrophobicity in adhesion. Appl Environ Microbiol 53:1893-1897.

Wan J, Wilson JL, Kieft TL. 1994. Influence of gas-water interface on transport of microorganisms through unsaturated porous media. Appl Environ Microbiol 60:509-516. 